\title{
Cambridge
}

\section{Putting Asunder}

\section{A History of Divorce in Western Society RODERICK PHILLIPS}

Treating Europe since the Middle Ages, North America since the seventeenth century and Australasia since the nineteenth century, this book offers the first comprehensive history of divorce and marriage breakdown in Western Society. .... provides a clear, intelligent, scholarly, and dependable general account of the history of divorce in the West'. Lawrence Stone, New York Review of Books $£ 30.00$ net $0521324343816 \mathrm{pp}$.

\section{Scottish Society, 1500-1800}

Edited by R. A. HOUSTON and I. D. WHYTE

This book surveys the considerable recent advances made in Scottish social history and presents some of the latest work from leading scholars, aiming to broaden the debate on Scottish society and to integrate it more closely with British and European social history.

$£ 30.00 \quad 0521325226290 \mathrm{pp}$. .

\section{Upland Communities}

Environment, Population and Social Structure in the Alps since the 16th Century PIER PAOLO VIAZZO

This book follows the social, economic and demographic transformations of the Alpine area from the late Middle Ages to the present day, its chronological and geographical breadth enabling the author to challenge a number of deeply-rooted but anachronistic notions about 'backward' mountain society in the past. £32.50 0521306639340 pp. Cambridge Studies in Population, Economy and Society in Past Time 8

\section{Demographic Behavior in the Past}

A Study of Fourteen German Village Populations in the 18th and 19th Centuries JOHN E. KNODEL

The core of this study deals with marital reproduction, examining the modemisation of reproductive behaviour in terms of the transition from natural fertility to pervasive family limitation: it also illuminates many aspects of demographic behaviour largely ignored by previous 'macro-level' studies. $£ 45.00$ net 0521327155612 pp.

Cambridge Studies in Population, Economy and Society in Past Time 6

\section{The Upheaval of War}

Family, Work and Welfare in Europe; 1914-18

Edited by RICHARD WALL and JAY WINTER

In a fully comparative, trans-European context, this book offers a unique examination of the destabilising effects of the First World War on family life, moving on to broader speculations about the impact of war on family forms and alternative social affiliations.

f40.00 $0521323452499 \mathrm{pp}$.

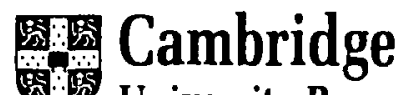

The Edinburgh Building, Cambridge CB2 2RU 


\section{Cambridge}

Now in paperback

The Fall of the House of Labor

The Workplace, the State, and American Labor Activism, 1865-1925 DAVID MONTGOMERY

'... as its subtitle suggests, the book is nothing less than a full-scale synthesis of working-class political and economic history ... The result is a richly detailed, subtle, sometimes difficult, and important book.'

The Times Literary Supplement

$£ 12.95$ net $\mathrm{Pb} \quad 0521379822494 \mathrm{pp}$.

Co-publication with the Maison des Sciences de l'Homme, Paris

\section{Now in paperback}

\section{Between the Devil and the Deep Blue Sea}

Merchant Seamen, Pirates and the Anglo-American Maritime World, 1700-1750

\section{MARCUS REDIKER}

'Good books have been written before on the history of seafaring and on the climactic years of piracy ... Rediker has written another good one ... What distinguishes Rediker's work is his unwavering and unsentimental focus on the seaman's labour and experience.'

E. P. Thompson, The Guardian

$£ 9.95$ net $\mathrm{Pb}, 0521379830337 \mathrm{pp}$.

\section{Work and Wages}

Natural Law, Politics and the Eighteenth-Century French Trades MICHAEL SONENSCHER

This original and extensive analysis of urban trades in eighteenthcentury France lays the foundations for a fresh approach to comparative studies of the workshop economy in European industrial history.

$£ 37.50$ net $0521329841472 \mathrm{pp}$.

Now in paperback

The Historical Meanings of Work

Edited by PATRICK JOYCE

'It is hard to do justice to this fine collection: each chapter merits careful consideration and, unlike many similar collections there are no passengers.'

f10.95 net Pb 0521366860326 pp.

Social History

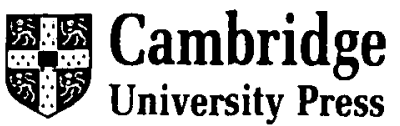

The Edinburgh Building, Cambridge CB2 2RU 